\title{
Mechanical and fatigue properties of CFRP plate reinforced steel structural interface
}

\author{
Hua Zhu
School of Civil Engineering, Yancheng Institute of Technology, Yancheng, Jiangsu, 224051, China

Received June 20, 2018

\begin{abstract}
The carbon fiber-reinforced polymer (CFRP) has high strength, low weight and corrosion resistance. In addition, CFRP can improve the fatigue properties of steel products. In this work, we study the mechanical and fatigue properties of a steel plate hardened with carbon fiber. Tensile studies with pressure control were carried out on a plate of steel reinforced with carbon fiber using an electro-hydraulic servo-amplifier machine for testing materials MTS810. Tests for fatigue strength of cracked steel plate and CFRP alloy were carried out at different stress amplitudes. When checking the fatigue characteristics, an increase in the amplitude of the bending force resulted in a decrease in the fatigue life of the specimens. It has been found that the mechanical properties of a steel plate hardened with carbon fiber at equal loads are better than that of a steel plate, and the fatigue life is greater.

Keywords: carbon fibre reinforced plastics plate, steel structure, mechanical property, fatigue property.
\end{abstract}

Армированный углеродным волокном полимер (CFRP) обладает высокой прочностью, малой массой и коррозионной стойкостью. Кроме того, CFRP может улучшить усталостные характеристики изделий из стали. В работе проведены исследования механических и усталостных свойств стальной пластины, упрочненной углепластиком. Исследования на растяжение с контролем давления проводили на пластине из стали, армированной углепластиком, используя электрогидравлическую сервоусилительную машину для испытаний материалов MTS810. Испытания на усталостную прочность крекированной стальной плиты и из сплава CFRP проводились при различных амплитудах напряжений. При проверке усталостных характеристик увеличение амплитуды напряжения изгибающей силы привело к уменьшению усталостного срока службы образцов. Обнаружено, что механические свойства стальной пластины, упрочненной углепластиком, при одинаковых нагрузках лучше, чем у стальной плиты, а усталостная долговечность больше.

Механічні і втомні властивості структурного інтерфейсу зі сталі, зміцненої вуглепластиком. Нua Zhu.

Армований вуглецевим волокном полімер (CFRP) має високу міцність, малу масу і корозійну стійкість. Крім того, CFRP може поліпшити втомні характеристики виробів зі сталі. У роботі проведено дослідження механічних і втомних властивостей сталевої пластини, зміцненої вуглепластиком. Дослідження на розтягнення з контролем тиску проводили на пластині зі сталі, армованої вуглепластиком, використовуючи електрогідравлічну сервопідсилюючу машину для випробувань матеріалів MTS810. Випробування на міцність від утоми крекірованої сталевої плити зі сплаву CFRP проводилися при різних амплітудах напруг. При перевірці втомних характеристик збільшення амплітуди напруги згинаючої сили призвело до зменшення втомного терміну служби зразків. Виявлено, що механічні властивості сталевої пластини, зміцненої вуглепластиком, при однакових навантаженнях кращі, ніж у сталевої плити, а втомна довговічність більше. 


\section{Introduction}

The steel structure has been widely used in engineering structures due to its good physical structure. However, the design failure or substandard component may lead to the failure of steel structure under the effects of external load, corrosion of the surrounding environment and some accidental factors in the process of use. To solve these problems, some reinforcement methods are often used for repairing or strengthening steel structure. The traditional reinforcement means [1] include bolted connection, rivet connection and welding, but they have shortcomings such as large consumption of time and energy, increase of self weight and easy corrosion of the reinforcement part. Therefore carbon fibre reinforced plastics (CFRP) plate is introduced for reinforcing steel structure. Fiber Reinforce Plastic (FRP) is composed of continuous fibers and resin matrix. Compared to the traditional metal reinforcement, CFRP plate can avoid the above shortcomings [2].

There are many studies concerning CFRP plate reinforcement. Fuller et al. in [3] studied a spread tow thin ply carbon-epoxy prepreg material with a cured ply thickness of $0.0302 \mathrm{~mm}$ and found that the application of angle-ply laminates could achieve highly non-linear stress-strain behaviour and suppress the damage mechanisms. Wang in [4] explored the mechanical performance of CFRP-confined square concrete columns under monotonic axial compression and found that the size of specimen had no significant influence on the axial stressstrain behavior of FRP-confined mediumand small-sized columns and the axial stress-strain response suggested difference with the increase of specimen size. Ressarchers in [5] fabricated CFRP by a prepreg-based hot press method and found it excellent in electrical conductivity in the thickness direction. In this study, pressurecontrolled tensile loading was performed on CFRP plate reinforced steel plate using MTS810 electro-hydraulic servo universal material testing machine, and the fatigue performance of cracked steel plate and CFRP plate reinforced cracked steel plate was tested under different stress amplitudes.

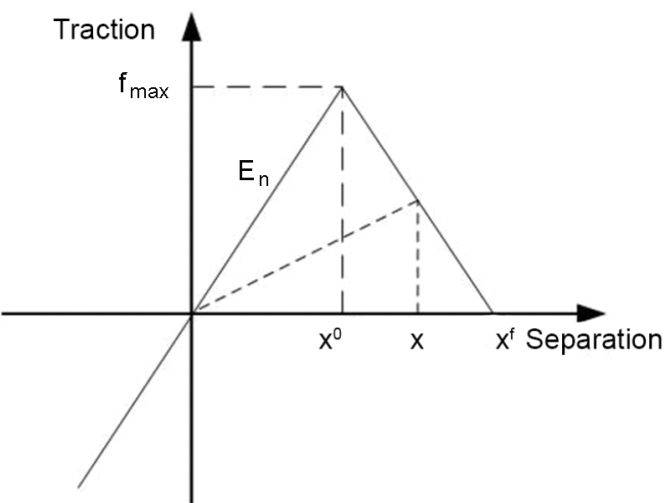

Fig. 1. The bonding separation model

\section{Mechanical and fatigue performance of CFRP plate reinforced steel}

The same material can produce different cracks under different loads in a fix ambient, and the cracks can be generally divided into opening mode, sliding mode crack and tearing mode crack. This paper only explained the opening node crack because of the limit of length. As shown in Fig. 1, it is the bond separation model of opening mode crack.

In Fig. 1, the vertical coordinate is the traction cohesion of crack surface, and the horizontal coordinate is the opening displacement of crack surface. It was noted from Fig. 1 that the glue line began to separate when the normal stress of the direction of thickness of glue line was $f_{\text {max }}$, and the traction gradually decreased to 0 with the increase of opening displacement. Its expression is:

$$
f=\left\{\begin{array}{l}
\frac{E_{a}}{d} x \quad x \leq x_{0} \\
\frac{E_{a}}{d} x(1-a) \quad x_{0} \leq x \leq x^{f} \\
0 \quad x \geq x^{f}
\end{array},\right.
$$

where $x$ is the opening displacement of cracks, $E_{a}$ is the elasticity modulus of glue line, $d$ is the thickness of glue line, and $a$ is damage factor.

The fatigue life of a structure generally includes crack forming life and crack growth life. Generally speaking, the theory of fracture mechanics is used for calculating crack growth life. The amplitude of stress intensity factor is closely related to crack growth life. Fig. 2 shows the logarithmic function curve of crack growth rate and the amplitude of stress intensity factor. 
Table 1. Data of the materials

\begin{tabular}{||c|c|c|c|c|c||}
\hline Item & Length, mm & Width, mm & Thickness, mm & $\begin{array}{c}\text { Tensile } \\
\text { strength, MPa }\end{array}$ & $\begin{array}{c}\text { Extension } \\
\text { modulus, GPa }\end{array}$ \\
\hline Q235 steel plate & 260 & 60 & 12 & 455 & 209 \\
CFRP plate & 180 & 60 & 1.3 & 3000 & 170 \\
Adhesive & $/$ & $/$ & $/$ & 55 & 4 \\
\hline
\end{tabular}

It is noted from Fig. 2 that the curve is divided into three areas. Area 1 is nongrowth area; when the amplitude of stress intensity factor is smaller than $\Delta K_{a}$, cracks nearly has no growth. Area 2 is stable growth area; when the amplitude of stress intensity factor is between $\Delta K_{a}$ and $\Delta K_{b}$, cracks grow stably, and the growth rate is in a linear logarithmic relationship with the amplitude of stress intensity factor

$$
\frac{d y}{d M}=A\left(\Delta K_{b)}^{n}\right.
$$

where $\Delta K_{b}=K_{b}(1-R), K_{\mathrm{b}}$ is the fracture toughness of material, $R$ is stress ratio, $A$ and $n$ are constants of material, $\Delta K$ is the amplitude of stress intensity factor, $y$ is the length of crack, and $M$ is the times of cycling. Area 3 is rapid growth area; at that time, cracks grow rapidly, and the material tends to fracture; its proportion in the fatigue life can be ignored.

When the amplitude of stress intensity factor and load remain unchanged, the fatigue life of a component can be speculated according to

$$
M=\frac{1}{A} \int_{y_{1}}^{y_{2}} \frac{d y}{(\Delta K)^{n}},
$$

where $y_{1}$ is the length of initial crack, $y_{2}$ is the length of crack after growth, and $M$ is the times of cycling.

\section{Experimental}

For test of mechanical performance material test was carried out on Q235 steel plate according to China National Standard GBT228-2002 [6]. CFRP plate used was produced by Stesalit AG company, and epoxy resin was used as adhesive [7]. The data of the materials are shown in Table 2.

The test specimen is shown in Fig. 3. Two steel plates were connected, and the joint was fixed using CFRP plate. The steel plate and fibre plate were connected using epoxy resin; before connection, the surface of the steel plate was processed [8]. As the

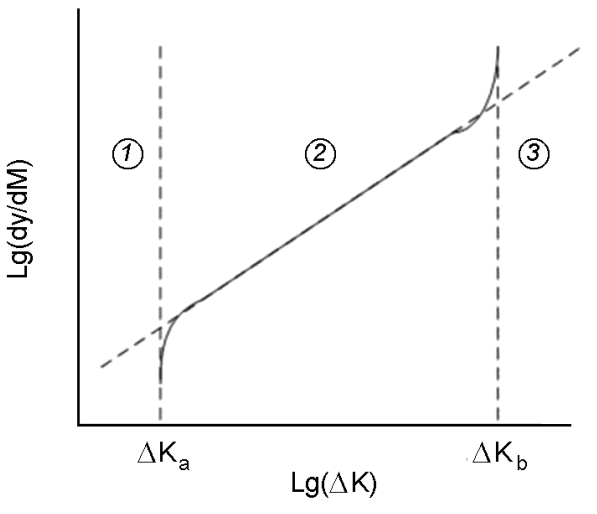

Fig. 2. The logarithmic curve of fatigue crack growth.

adhesive might not be coated evenly and there might be a loss in surface processing, the test specimen was measured before static stretching [9].

For test of fatigue performance Q235 steel plate was used. The CFRP plate used was the same with that used in the mechanical performance test. The parameters of the test specimens are shown in Table 2 .

As shown in Fig. 4, test specimen $\mathrm{X}$ is a cracked steel plate, and a $10 \mathrm{~mm}$ long crack was made in the middle of the test specimen using wire; text specimen was pasted with a CFRP plate which was $1.3 \mathrm{~mm}$ thick, 80 $\mathrm{mm}$ long and $40 \mathrm{~mm}$ wide on the upper and lower surfaces of the crack. Surface processing was made before bonding.

Pressure-controlled tensile loading was performed using MTS810 electro-hydraulic servo universal material testing machine. The loading speed was $0.3 \mathrm{kN} / \mathrm{s}, 5 \mathrm{kN}$ for one grade, and each grade was kept for $3 \mathrm{~s}$. Firstly it was pre-loaded to $10 \mathrm{kN}$ at a speed of $0.4 \mathrm{kN} / \mathrm{s}$ and then unloaded. The procedures of the subsequent test were as follows. The computer was turned on, and the testing system was logged on. Then the oil pump and regulating valve were opened [11] to make upper beam rise. The experimental scheme was edited in the system. The test specimens were installed using proper fixture. Test specimen A was pasted with a force transmission steel plate which was $60 \mathrm{~mm}$ wide on the left side. Test speci- 
Table 2. Data of the materials.

\begin{tabular}{|c|c|c|c|c|c||}
\hline \hline Item & Length, mm & Width, mm & Thickness, mm & $\begin{array}{c}\text { Tensile } \\
\text { strength, MPa }\end{array}$ & $\begin{array}{c}\text { Extension } \\
\text { modulus, GPa }\end{array}$ \\
\hline Q235 steel plate & 170 & 40 & 3 & 455 & 209 \\
CFRP plate & 80 & 40 & 1.3 & 3000 & 170 \\
Adhesive & $/$ & $/$ & $/$ & 55 & 4 \\
\hline
\end{tabular}

$$
12 \overline{\mathrm{mm}}
$$

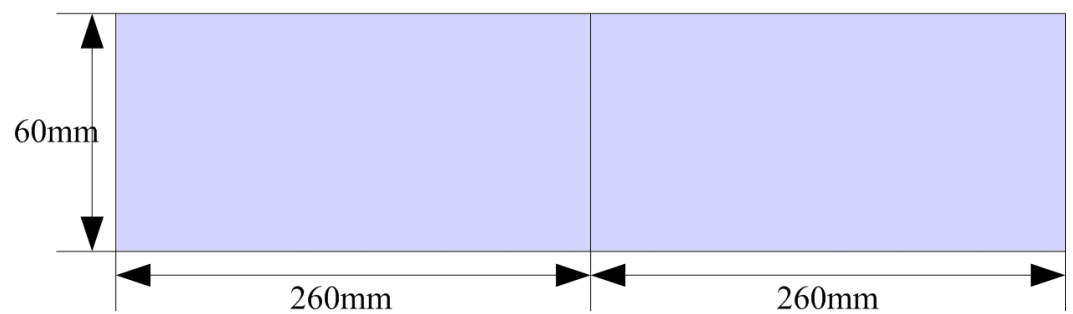

Fig. 3. Design of test specimen component

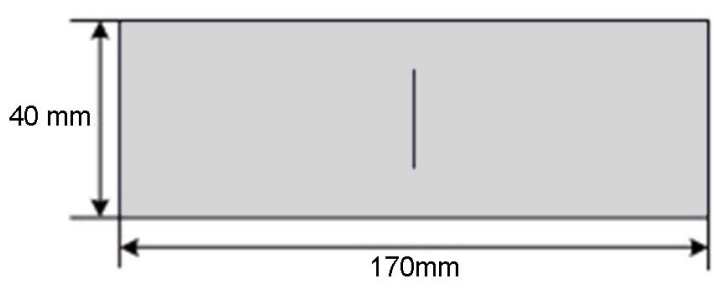

(X) Cracked steel plate

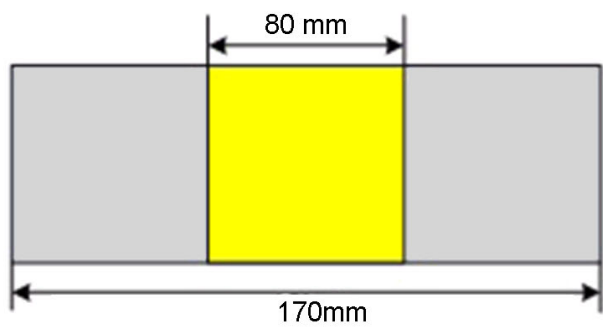

(Y) CFRP plate reinforced cracked steel plate

Fig. 4. Design of test specimen component

men B was pasted with force transmission steel plate which was $30 \mathrm{~mm}$ wide on both sides. Test specimen $\mathrm{C}$ was pasted with force transmission steel plate which was 60 $\mathrm{mm}$ on the both sides. Moreover the measure points of strain meter which were used for measuring stress should be distributed at the joint or two ends of the steel plates if possible. Then the testing machine worked until the test specimen was damaged. Finally the fixture was removed.

3.2.2 Test of fatigue performance

Bending fold test [10] was carried out on test specimen $\mathrm{X}$ and $\mathrm{Y}$ under stress amplitudes using a MTS810 electro-hydraulic servo universal material testing machine; the stress amplitude was $150 \mathrm{MPa}$ and 250 $\mathrm{MPa}$, and the stress ratio was 0.1 . To prevent degumming of the ends of CFRP plate, the two ends were clamped using bolt clip. Each test specimen was tested thrice under each stress amplitude.

\section{Results and discussion}

As shown in Table 3 , the actual thickness of the three steel plate specimens was different with the theoretical thickness due to the surface processing of the steel plates and uneven glue line.

Overall, the test phenomenon of the three test specimens was similar. Taking test specimen $\mathrm{C}$ in Fig. 5 as an example, the strain of test specimen $C$ gradually increased with the increase of load in the initial stage of loading, but only the interface of the steel plate had obvious changes. When the load reached $65 \%$ of the ultimate load, CFRP plate began to crack and fizz, and the stress area of the test specimen began to move to the two ends of the plate. With the continuous increase of the load, the strain value also increased; but the surface of the component had no change. When the load reached the limit, a loud sound was heard, the CFRP plate was separated from the steel plate, and the load rapidly de- 
Table 3. The measured thickness of the test specimen

\begin{tabular}{||c|c|c|c||}
\hline $\begin{array}{c}\text { No. of } \\
\text { test } \\
\text { specimen }\end{array}$ & $\begin{array}{c}\text { Thickness } \\
\text { of steel } \\
\text { plate/mm }\end{array}$ & $\begin{array}{c}\text { Thickness } \\
\text { of test } \\
\text { specimen/mm }\end{array}$ & $\begin{array}{c}\text { Thickness } \\
\text { of glue } \\
\text { line/mm }\end{array}$ \\
\hline A & 11.52 & 16.82 & 1.45 \\
B & 11.57 & 17.23 & 1.63 \\
C & 11.63 & 16.65 & 1.31 \\
\hline
\end{tabular}

creased to 0 . The test specimen was directly damaged, and the load stopped.

There are three kinds of failure types in components [12], as shown in Table 4.

According to Table 4, the failure type of test specimen B was stripping failure of CFRP plate/glue line, and the failure type of test specimen $\mathrm{A}$ and $\mathrm{C}$ was delamination failure of CFRP plate. The test results demonstrated that the failure of the test specimen was shear-bond failure, and stripping of CFRP plate started when the shear stress reached the limited at the interface.

Analysis on the bearing capacity of CFRP plate reinforced steel plate Figs. 6, 7 and 8 shows the strain-load curves of test specimen $\mathrm{A}, \mathrm{B}$ and $\mathrm{C}$.

(1) Test specimen $A$

In the early stage of loading, i.e., before $40 \mathrm{kN}$, the strain changes around the end and interface of the CFRP plate were linear. After $50 \mathrm{kN}$, the strain around the end of the CFRP plate basically had no changes, and the strain around the interface grew rapidly. The strain increased $75 \%$ when the load increased from $50 \mathrm{kN}$ to the ultimate, suggesting the shear stress around the interface grew rapidly in that stage; but the shear stress around the end of the CFRP plate remained unchanged. The zone of action moved from the end of the CFRP plate to the area around the interface. The shear stress around the interface reached the ultimate shear stress, and shear failure happened to test specimen $\mathrm{A}$.

(2) Test specimen B

In the early stage of loading, i.e., before $30 \mathrm{kN}$, strain changes around the end and interface of CFRP plate were linear. After $33 \mathrm{kN}$, the strain around the end of the CFRP plate had little change, but the strain around the interface grew rapidly. The strain increased $106 \%$ when the load increased from $33 \mathrm{kN}$ to $40 \mathrm{kN}$; after $40 \mathrm{kN}$, the increase was almost linear. The strain increased $250 \%$ when the load increased from $33 \mathrm{kN}$ to the ultimate. Besides the stress of the end of the CFRP plate linearly increased when the load approached the ul-
Table 4 . The failure types of components

\begin{tabular}{||c|c||}
\hline Failure types & Failure forms \\
\hline $\begin{array}{c}\text { Stripping failure of } \\
\text { CFRP plate/glue line }\end{array}$ & $\begin{array}{c}\text { Glue line completely } \\
\text { pasted on steel plate } \\
\text { Stripping failure of } \\
\text { steel plate/glue line } \\
\text { Delamination failure } \\
\text { of CFRP plate } \\
\text { completely separate. } \\
\text { It is universal and } \\
\text { usually occurs inside } \\
\text { CFRP plate. Some fibers } \\
\text { stay at glue line after } \\
\text { failure of test specimen. }\end{array}$ \\
\hline
\end{tabular}

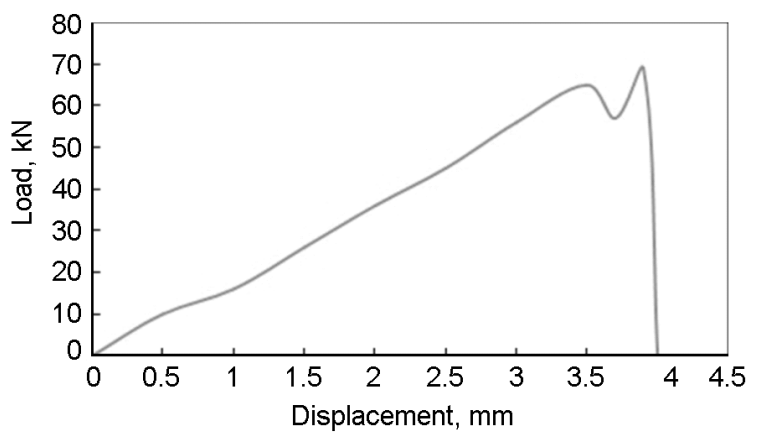

Fig. 5. The load-displacement curve of test specimen $\mathrm{C}$.

timate, suggesting that the shear stress around the end and interface of the CFRP plate increased rapidly at the moment. Test specimen B was damaged when it reached the ultimate shear stress.

(3) Test specimen C

In the early stage of loading, the strain changes around the end and interface of the CFRP plate was linear. The strain around the end of the CFRP plate had little change when the load was larger than $30 \mathrm{kN}$, and the strain around the interface transiently had little change when the load was between 30 and $40 \mathrm{kN}$. But the strain around the interface had a rapid linear increase when the load was higher than $40 \mathrm{kN}$. The strain increased $185 \%$ when the load increased from $40 \mathrm{kN}$ to $60 \mathrm{kN}$. After $60 \mathrm{kN}$, the strain increased linearly, but the increase amplitude was smaller. The strain increased $280 \%$ when the load increased from $40 \mathrm{kN}$ to the ultimate, indicating that the shear stress around test specimen $\mathrm{C}$ grew rapidly and was the first to reach the ultimate; shear failure happened to test specimen C.

The test results of specimen $\mathrm{X}$ were similar when the stress amplitude was $150 \mathrm{MPa}$ and $250 \mathrm{MPa}$. The fatigue source located at the two ends of the original crack. In the process of bending fold, the crack grew, and the steel plate around the crack tip had obvious plastic deformation. The test re- 
Table 5. The fatigue life of the test specimens

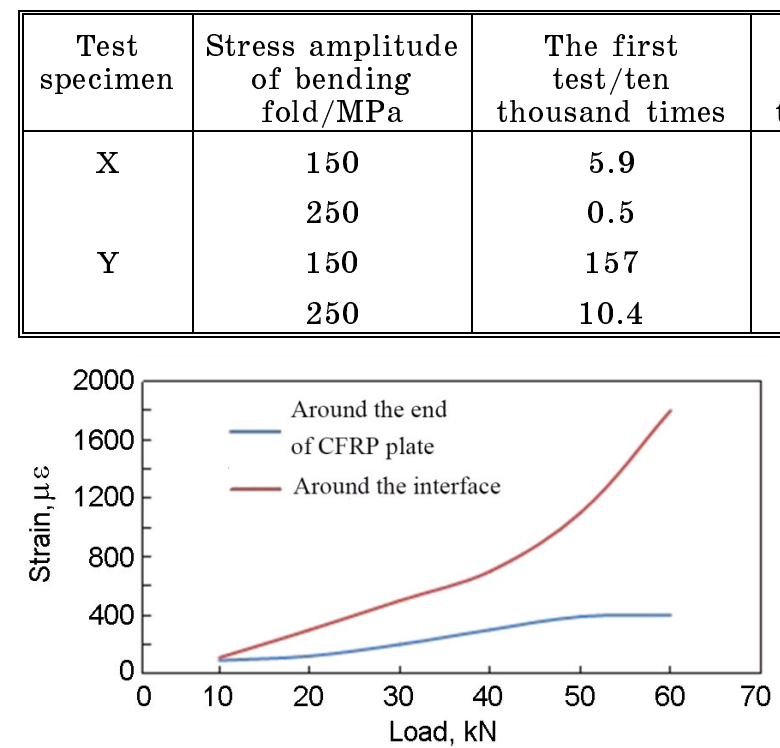

Fig. 6. The strain-load curves of test specimen A before failure.

sults of test specimen $\mathrm{Y}$ were also similar when the stress amplitude was $150 \mathrm{MPa}$ and $250 \mathrm{MPa}$. After complete fracture of the steel plate, the CFRP plate still could carry bending fold. After the CFRP plate was dissembled, the metal fatigue source was found at the two ends of the original crack; the crack grew from the two ends, but the opening of the crack surface was smaller compared to test specimen $\mathrm{X}$. Moreover test specimen $\mathrm{Y}$ constantly fizzed in the late stage of bending fold, which was because that the CFRP plate began to fracture slightly.

Table 5 exhibits that no matter CFRP plate was used for reinforcement or not, the fatigue life of the test specimens reduced greatly with the increase of the stress amplitude of bending fold; when the stress amplitude was $150 \mathrm{MPa}$, the average life of test specimen $\mathrm{X}$, i.e. the cracked steel plate, was 56,000 times, and the average life of test specimen Y, i.e. CFRP plate reinforced cracked steel plate was 1.56 million times, improved 26.86 times. When the stress amplitude was $250 \mathrm{MPa}$, the average life of test specimen $\mathrm{X}$ and $\mathrm{Y}$ was 5,000 times and 102,000 times, improved 19.4 times. When the stress amplitudes of bending fold were the same, the fatigue life of the CFRP plate reinforced cracked steel plate was longer than that of the cracked steel plate, indicating CFRP plate reinforcement could effectively improve the fatigue life of cracked steel plates.

\begin{tabular}{|c|c|c||}
$\begin{array}{c}\text { The second } \\
\text { test/ten } \\
\text { thousand times }\end{array}$ & $\begin{array}{c}\text { The third } \\
\text { test/ten } \\
\text { thousand times }\end{array}$ & $\begin{array}{c}\text { Average/ten } \\
\text { thousand times }\end{array}$ \\
\hline 5.4 & 5.5 & 5.6 \\
0.6 & 0.4 & 0.5 \\
155 & 156 & 156 \\
10 & 10.1 & 10.2 \\
\hline
\end{tabular}

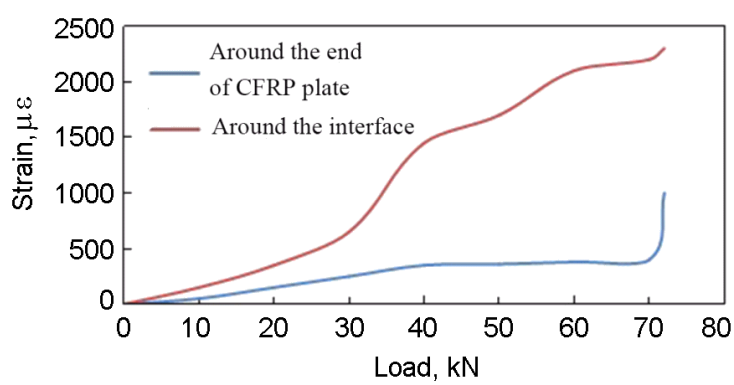

Fig. 7. The strain-load curves of test specimen $\mathrm{B}$ before failure.

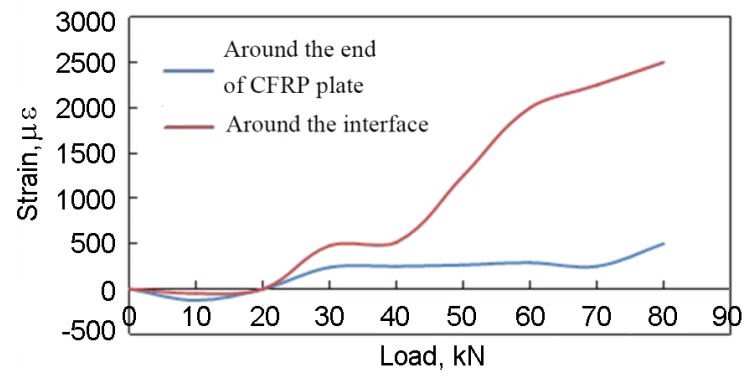

Fig. 8. The strain-load curves of test specimen $\mathrm{C}$ before damage.

\section{Conclusions}

Pressure-controlled tensile loading was performed on CFRP plate reinforced steel plate using a MTS810 electro-hydraulic servo universal material testing machine. The fatigue performance of cracked steel plate and CFRP plate reinforced cracked steel plate was tested under different stress amplitudes. The conclusions are as follows.

The test results of the three components were similar in the tensile test. When the load was $65 \%$ that of the ultimate load, the CFRP plate began to fracture and fizz. When the load increased to the limit, a loud sound was heard, and the CFRP plate was separated from the steel plate. The failure of test specimen $\mathrm{A}$ and $\mathrm{C}$ was delamination failure of CFRP plate, and the failure of test specimen B was stripping failure of steel plate/glue line. 
In the tensile test, test specimen A only had force transmission steel plate which was $60 \mathrm{~mm}$ wide on one end. Test specimen $\mathrm{B}$ and $\mathrm{C}$ had force transmission plate on two ends; and the width was $30 \mathrm{~mm}$ and $60 \mathrm{~mm}$ respectively. In the initial stage of loading, the strain and load of the three test specimens was in a linear relationship. But in the middle stage of loading, the shear stress around the interface of the steel plate rapidly increased, but the shear stress around the plate end remained unchanged; the shear stress around the interface reached the limit firstly, and shear failure happened to the test specimen. When the load of test specimen B was close to the limit, the stress on the end of the CFRP plate increased linearly, and the shear stress around the end and interface of test specimen $B$ sharply increased; the test specimen failed when the shear stress reached the limit.

In the test of fatigue performance, the increase of stress amplitude of bending fold greatly shortened the fatigue life of the test specimens. The average fatigue life of the CFRP plate reinforced cracked steel plate improved 26.86 times under the stress amplitude of $150 \mathrm{MPa}$ and 19.4 times under the stress amplitude of $250 \mathrm{MPa}$. It indicated that the fatigue resistance performance of the CFRP plate reinforced cracked steel plate was higher and CFRP plate could extend the fatigue life of steel plates.

\section{References}

1. B. Simogshan, K. Kaviya., IJETR, 6(6), 934 (2017).

2. S. Selvaraj, M. Madhavan, Thin-Wall Struct., 108, 109 (2016).

3. J.D. Fuller, M.R. Wisnom, Comp. Part A Appl. Sci. \& Manufact., Compos. Part A-Appl. S., 69, 64 (2015).

4. D.Y. Wang, Z.Y. Wang, S.T. Smith, T. Yu, Constr. Build. Mater., 118, 116 (2016).

5. T. Yokozeki, T. Goto, T. Takahashi, et al., Compos. Sci. Technol., 117, 2771 (2015).

6. Q. Liu, Z. Mo, Y. Wu, et al., Compos. Part B Eng., 98, 406 (2016).

7. X. Wang, A.M. Sayed, Z. Wu, J. Struct. Eng., 141, 04014189 (2015).

8. R. Kotynia, M. Staskiewicz, J. Michels et al., in: SMAR 2015 - Third Conf. Smart Monitoring, Assessment and Rehabilitation of Civil Structures, in Antalya, Turkey (2015).

9. S. Selvaraj, M. Madhavan, Thin-Wall. Struct., 108, 109 (2016).

10. A. Hosseini, E. Ghafoori, M. Motavalli, et al., in: Conf. Smart Monitoring, Assessment and Rehabilitation of Civil Structures. in Zurich, Switzerland (2017).

11. H.T. Wang, G. Wu, J.B. Jiang, J. Compos. Constr., 20, 04015078 (2016).

12. Y. Liu, H. Peng, C.S. Cai, Adv. Struct. Eng., 18, 629 (2015). 